\title{
Apparent Continuing Expansion in the Range of the Gray Treefrog, Hyla versicolor, in New Brunswick
}

\author{
Donald F. McAlpine ${ }^{1}$, Joseph D. H. Pratt ${ }^{1,2}$, and John M. Terhune ${ }^{2}$ \\ ${ }^{1}$ New Brunswick Museum, 277 Douglas Avenue, Saint John, New Brunswick E2K 1E5 Canada; e-mail: donald.mcalpine@ \\ nbm-mnb.ca \\ ${ }^{2}$ Biology Department, University of New Brunswick, Saint John, New Brunswick, Canada
}

McAlpine, Donald F., Joseph D. H. Pratt, and John M. Terhune. 2009. Apparent continuing expansion in the range of the Gray Treefrog, Hyla versicolor, in New Brunswick. Canadian Field-Naturalist 123(4): 309-312.

Recent observations of the Gray Treefrog, Hyla versicolor, in the Maritimes suggest that this species may be expanding its range and abundance, perhaps partly in response to human activities. However, during the breeding season the species characteristically calls in very small choruses in the region and may be present but not call, or call for very short periods. This has made it difficult to determine distribution and to make an assessment of unconfirmed historic records that suggest presence beyond the current range more than 50 years ago. The inadvertent introduction of frogs may also be playing a role in the apparent recent range expansion of this species.

Key Words: Gray Treefrog, Hyla versicolor, distribution, New Brunswick, Nova Scotia.

The Gray Treefrog (Hyla versicolor) reaches its northeastern range limit in New Brunswick (Logier 1952, without citing a specific locality) although it is common elsewhere in Canada from southern Manitoba to southwestern Quebec (Cook 1984; Desroches and Rodrigue 2004). As recently as 1980 the species was known in the Maritimes only from Barker's Point, New Brunswick, a marsh about $120 \mathrm{~km}$ northeast of the nearest Maine population (Bleakney 1954; 1958; McAlpine et al. 1980). At that time concern for the survival of the Gray Treefrog in New Brunswick was such that it was proposed as a candidate for endangered species status in the province (Stewart 1974; Majka 1981). Canada's first protected site for an amphibian was established in New Brunswick on behalf of this species (McAlpine and Vail 2005). However, investigations in 1980-1990 in southwestern New Brunswick showed $H$. versicolor to be neither rare nor endangered in the province (McAlpine et al. 1991) and the species is now considered secure (CESCC 2006). McAlpine (1997) suggested that the species range in New Brunswick was expanding, perhaps partly in response to access to suitable breeding habitat created through human activities. Here we document what appears to be continuing expansion in the range of this species in the Maritimes.

Information on calling Gray Treefrogs was collected opportunistically following reports of calling and through field investigation in suitable habitat during the known calling period for the region. Calls were recorded on several occassions using hand-held cassette recorders and the pulse repetion rates were measured from sound spectrograms (Spectrogram v 15.0, Visulizing Software LLC). Where possible voucher specimens were also collected and have been deposit- ed in the collections of the New Brunswick Museum (NBM).

McAlpine et al. (1991) documented new locations for the Gray Treefrog in western New Brunswick, mostly along the Maine-New Brunswick border, which closed the distributional gap between Barker's Point and Maine populations to about $68 \mathrm{~km}$. The Gray Treefrog has been known to be resident at Barker's Point since about 1935 and in the general area since about 1899 (McAlpine et al. 1980). In 2002 a single $H$. versicolor was reported to call for about 15 minutes on 22 July at English Settlement $\left(46.261^{\circ} \mathrm{N}\right.$ $66.730^{\circ} \mathrm{W}$ ), York County, about $30 \mathrm{~km}$ north of Barker's Point, by long-time residents and local naturalists Robert Whitney and Julie Singleton. No other calling was noted in that year. At least three frogs were heard calling at English Settlement on 17 June 2003. Calling has been noted from Magaguadavic $\left(45.766^{\circ} \mathrm{N} 67.164^{\circ} \mathrm{W}\right)$ west to McAdam $\left(45.594^{\circ} \mathrm{N}\right.$ $\left.67.164^{\circ} \mathrm{W}\right)$, York County and north to North Lake, Carelton County $\left(45.820^{\circ} \mathrm{N} 67.721^{\circ} \mathrm{W}\right)$ on the MaineNew Brunswick border (D. L. Sabine, A. W. Thomas, personal communication to DFM).

On 1-2 July 2004 a single Gray Treefrog was photographed and the call recorded at a pond close to a large roadside farm market near Wolfville, Kings County, Nova Scotia $\left(45.085^{\circ} \mathrm{N} 64.387^{\circ} \mathrm{W}\right)$. The frog called for several weeks at the site but no Gray Treefrogs have been heard calling at the pond in subsequent years. Analysis of the call, which presents a pulse rate of 20.8/sec, confirms that the frog is H. versicolor (Figure 1), which has a significantly slower pulse repetion rate at a given air temperature than its sibling species, H. chrysoscelis (Cope's Gray Treefrog) (Bogart and Jaslow 1979). Air temperature data from 


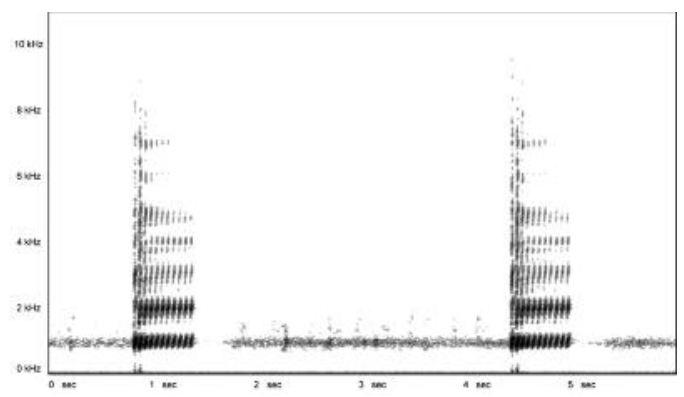

FIGURE 1. Sound spectrogram showing two trills of Hyla versicolor (analyzing bandwidth of $86.1 \mathrm{~Hz}$ ). Recording was made 2 July 2004 at Wolfville, Nova Scotia.

the Environment Canada Hourly Data Report (www. climate.weatheroffice.ec.gc.ca) recorded at the nearby Kentville weather station suggests air temperature at the calling site was in the low $20 \mathrm{~s}^{\circ} \mathrm{C}$ the night the recording was made.

On 25-26 June 2005 Roy LaPointe recorded a single Gray Treefrog calling at about $2130 \mathrm{hrs}$ at a recorded air temperature of $23^{\circ} \mathrm{C}$ at St. Jacques $\left(47.416^{\circ} \mathrm{N}\right.$ $68.383^{\circ} \mathrm{W}$.), a community near Edmunston, Madawaska County, New Brunswick. Analysis of the call, showing a pulse rate of 25.0/sec (Figure 2), demonstrates that the species is also H. versicolor. The frog was calling from hardwood trees surrounding a wetland area created in waste land adjacent to the Trans-Canada Highway. DFM and others visited the site on 26 June 2008. Weather data suggests that air temperature was several degrees warmer than in 2005 but no Gray Treefrogs were calling. Other apparently suitable wetlands in the area were also visited that night without success.

On 2 July 2008 DFM and JDHP visited Minto, Queens County, New Brunswick following reports of calls believed to be those of $H$. versicolor heard between 7 June and 1 July 2008. Small choruses were confirmed at two sites and voucher specimens collected (NBM 8852, 8853). Sites were typical wetlands for the species in the province. Fewer than 10 frogs were calling from a Beaver pond off a meander in Newcastle Stream $\left(46.074^{\circ} \mathrm{N} 66.067^{\circ} \mathrm{W}\right)$ and two frogs were calling from a small roadside pond $\left(46.084^{\circ} \mathrm{N}\right.$ $66.029^{\circ} \mathrm{W}$ ) created through excavation about $3 \mathrm{~km}$ northeast of the Beaver pond. No Gray Treefrogs were heard calling on previous trips to these sites by DFM on 9 and 14 June 2008, although a strong chorus was calling in light rain on the first evening at the longknown Barker's Point site, about $50 \mathrm{~km}$ southwest. Figure 3A plots the distribution of historic and new Gray Treefrog records reported and discussed here.

The observations above support earlier suggestions that the distribution and abundance of this species at

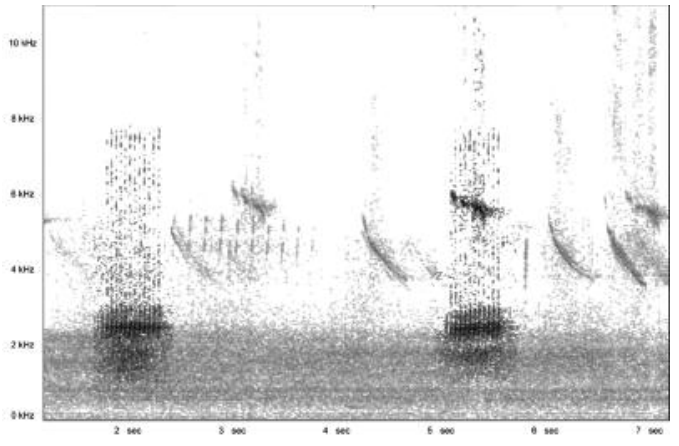

FIGURE 2. Sound spectrogram showing two trills of a Hyla versicolor (analyzing bandwidth of $21.5 \mathrm{~Hz}$ ). Recording was made 26 June 2005 at St. Jacques, New Brunswick. Accompanying down-sweeps are Redwinged Blackbird calls (Agelaius phoeniceus); traffic noise occupies the $0-2 \mathrm{kHz}$ range.

the margin of its northeastern range (see Figure 3B) may be enhanced by human activities. Calling sites typically occur where small-medium size wetlands have been created through road construction or the removal of the overburden. Association with Beaver ponds is also common. Documenting the species presence through calling has often been opportunistic as it has proven difficult to predict when or if small choruses will be calling during the breeding season. Ritke et al. (1992) found that climatic conditions alone are not responsible for inititiating breeding activity in the closely related $H$. chrysoscelis but suggested that the presence of gravid females may be important. Although $H$. versicolor is cryptic, it is tempting to believe it is unlikely to have been overlooked previously over such a wide range in New Brunswick, especially given the frequency with which reports are now being received. Nonetheless, the recent "redicovery" of Pseudacris brimleyi (Brimley's Chorus Frog) on the 80, 267 ha Savannah River Site, Georgia, after more than 50 years of relatively intense herpetological study (Luhring 2008), emphasizes how difficult it can be to detect the presence of some species and to pronounce on species presence, absence, or range expansion.

The St. Jacque record lends credence to unsupported 1947 and 1955 reports for three $H$. versicolor caught in insect light traps near Third Lake, Madawaska County, a site about $45 \mathrm{~km}$ north of the St. Jacques (see McAlpine et al. 1980, Figure 3A). St. Jacques falls within several narrow extentions of the federally established Saint John River Valley Ecoregion that follow river valleys in northern New Brunswick. Although Third Lake is in a different ecoregion (Northern New Brunswick Uplands), seasonal temperature and rainfall regimes for the two regions are very similar (Ecosystem Stratification Working Group 1995). The somewhat different provincial land classification system for 


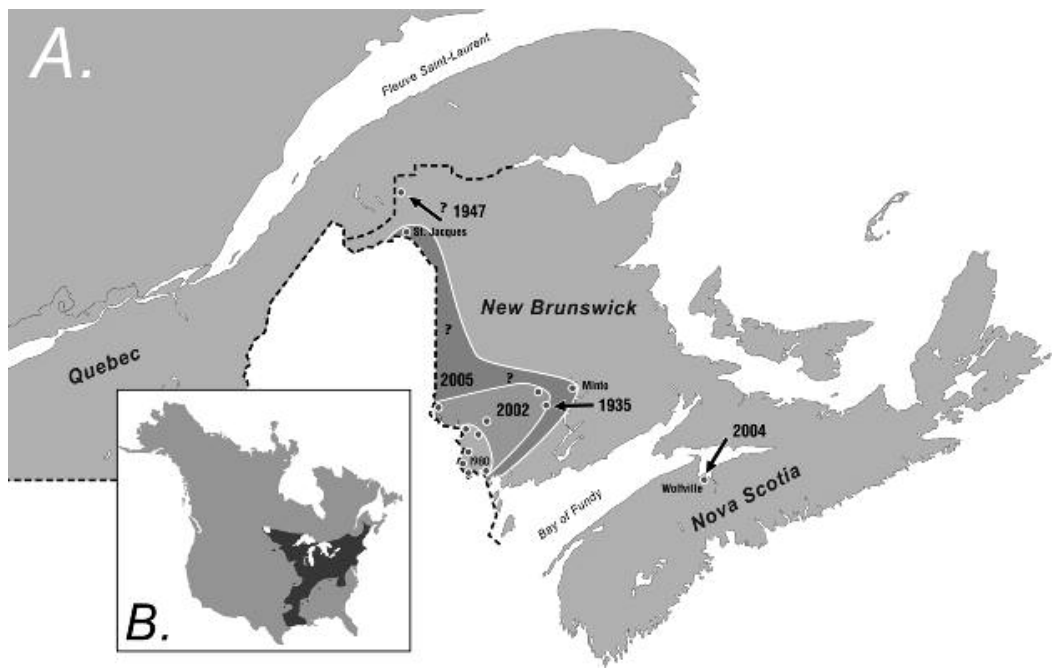

FIGURE 3(A). Historic and current reports of the Gray Treefrog in the Maritimes showing expanding understanding of range. Dots indicate confirmed occurrences; lines enclose estimated range. Approximate year at which presence was first demonstrated is also shown; (B). Inset, modified after Elliott et al. (2009) Shows North American range for the Gray Tree Frog with current distribution in the Maritimes incorporated. The isolated Nova Scotia report is not included.

New Brunswick reflects this in that both these sites are encompassed by Madawaska Ecodistrict 3-1 (Zelazny 2007). Given the sproadic nature of calling in this species at the northern edge of its range, it is worth noting that observers at Third Lake specifically noted that they had never heard the species calling in 1947 or 1955. However, past confusion with the abundant and widespread Spring Peeper (Pseudacris crucifer), make it difficult to assess the reliability of historic reports that are unsupported by specimens (Majka 1974).

It is likely that the Gray Treefrog recorded in Wolfville is an introduction, perhaps inadvertent. Although recorded for the province by Jones (1865) on the basis of a single second-hand report, and later by McKay (1896), the presence of this species in Nova Scotia has been discounted (Bleakney 1958; Gilhen 1984). The Wolfville site is along a secondary, but heavily travelled, highway and receives significant tourist traffic. The market farm where the frog was recorded is equipped with greenhouses that receive plant shipments from the eastern United States, a nature trail, and some exotic species are kept in a small petting zoo. Nonetheless, given the possible range expansion underway in adjacent New Brunswick, the often small choruses that characterize this species here, and that frogs may be present but may call infrequently, or perhaps not at all in some years, this occurrence in Nova Scotia is noteworthy. The inadvertent movement of $\mathrm{H}$. versicolor on shipped plant material, logging trucks, and by other means should not be overlooked as a mechanism in what may be this species on-going dispersal in the region.

\section{Acknowledgments}

We thank Elizabeth Mills and Stuart Tingley for ensuring reports of suspected Gray Treefrog calling in Minto were reported to us and for guiding us to sites. Harold Forsyth and Roy Lapointe graciously provided information and access to calls they had recorded. Dwayne Sabine, Julie Singleton, Tony Thomas and Robert Whitney also shared information with us. Vicky Lentz graciously provided accommodation in Edmunston during field work in the area and helped direct us to several wetlands. We also thank Amber McAlpine, Jordon Quan, Xuan Yang, Katelynne Vanderbrock, and Karen Vanderwolf for field assistance. Two reviewers provided very useful comments.

\section{Literature Cited}

Bleakney, J. S. 1954. Range extensions of amphibians in eastern Canada. Canadian Field-Naturalist 68: 165-1716

Bleakney, J. S. 1958. A zoogeographical study of the amphibians and reptiles of eastern Canada. National Museums of Canada Bulletin 155: 1-119.

Bogart, J. P., and A. P. Jaslow. 1979. Distribution and call parameters of Hyla chrysoscelis and Hyla versicolor in Michigan. Royal Ontario Museum Life Science Contributions 117: 1-13.

Cook, F. R. 1984. Introduction to Canadian Amphibians and Reptiles. National Museum of Natural Sciences, Ottawa. 200 pages.

Desroches, J. F., et D. Rodrigue. 2004. Amphibiens et reptiles du Québec et des Maritimes. Éditions Michel Quintin, Waterloo, Québec. 288 pages. 
Ecosystem Stratification Working Group. 1995. A National Ecological Framework for Canada. Agriculture and AgriFood Canada/Environment Canada. Ottawa.

Elliott, L., C. Gerhart, and C. Davidson. 2009. The frogs and toads of North America. Houghton Mifflin Harcourt, Boston and New York.

Gilhen, J. 1984. Amphibians and reptiles of Nova Scotia. Nova Scotia Museum, Halifax, Nova Scotia.

Jones, J. M. 1865. Contributions to the natural history of Nova Scotia: Reptilia. Transactions of the Nova Scotian Institute of Science 1: 114-128.

Luhring, T. M. 2008. "Problem species" of the Savannah River Site, such as Brimley's Chorus frog (Pseudacris brimleyi), demonstrate the hidden biodiversity concept on an intensively studied government reserve. Southeastern Naturalist 7: 371-373.

Logier, E. B. S. 1952. The frogs, toads and salamanders of eastern Canada. Clarke, Irwin \& Company Limited, Toronto, Ontario.

Majka, C. G. 1974. A deletion in the known range of the Gray Treefrog (Hyla versicolor) in northern New Brunswick. Canadian Field-Naturalist 88: 498.

Majka, M. 1981. Gray Treefrog: an endangered species in New Brunswick. NB Naturalist 11: 45-46.

McAlpine, D. F., S. W. Gorham, and A. D. B. Heward. 1980. Distributional status and aspects of the biology of the Gray Treefrog, Hyla versicolor, in New Brunswick. Journal of the New Brunswick Museum (1980): 92-102.
McAlpine, D. F., T. J. Fletcher, S. W. Gorham, and I. T. Gorham. 1991. Distribution and habitat of the Tetraploid Gray Treefrog, Hyla versicolor, in New Brunswick and Eastern Maine. Canadian Field-Naturalist 105: 526-529.

McAlpine, D. F. 1997. Historical evidence does not suggest New Brunswick amphibians have declined. Pages 117127 in Amphibians in decline: Canadian studies of a global problem. Edited by D. M. Green. Herpetological Conservation 1, Society for the Study of Amphibians and Reptiles, St. Louis, Missouri.

McAlpine, D. F., and D. A. Vail. 2005. Hyla Park: managing an amphibian conservation area in an eastern Canadian urban setting. Herpetological Bulletin 94: 17-21.

McKay, A. H. 1896. Batrachia and reptilia of Nova Scotia. Transactions of the Nova Scotian Institute of Science 2: 101-102.

Ritke, M. E., J. G. Babb, and M. K. Ritke. 1992. Temporal patterns of reproductive activity in the Gray Treefrog (Hyla chrysoscelis). Journal of Herpetology 26: 107-111.

Stewart, D. 1974. Canadian Endangered Species. Gage Publishing Company. Toronto.

Zelazny, V. F. Editor. 2007. Our landscape heritage: the story of ecological land classification in New Brunswick. New Brunswick department of Natural Resources.

Received 5 February 2009

Accepted 10 May 2010 